\title{
The effect of religion on poverty
}

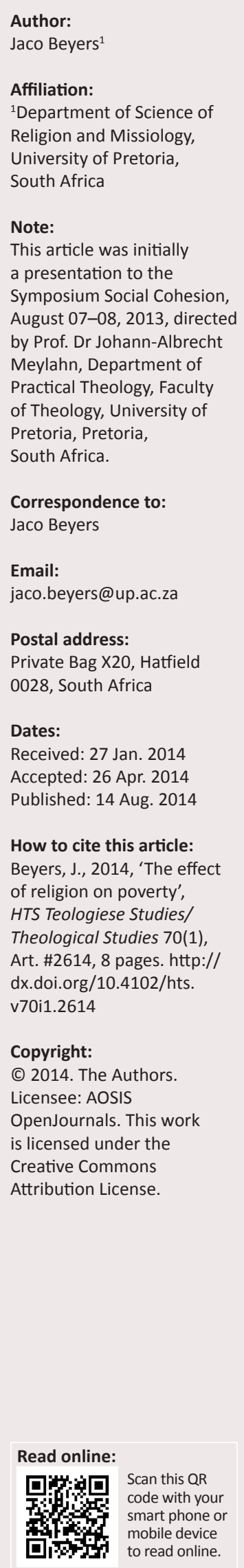

Poverty is a human condition. Social, economic, psychological and political factors affect society and can alleviate as well as stimulate poverty. Religion provides a unique perspective on the phenomenon of poverty. This article suggests three functions of religion regarding poverty. Firstly, religion can redirect human thought to spiritual concerns, focusing on spiritual poverty instead of material concerns. Secondly, it can provide the moral fibres needed in society. Religion can influence the response to poverty by having an ethical impact when principles benefiting all in society are applied within economic systems. Religion can also influence the response to poverty by fostering an attitude of willingness to practise generosity. Religion can educate communities in order for human dignity of all in society to be restored. Thirdly, religion can be part of the system actively encouraging and participating in alleviating poverty.

\section{Introduction}

Religion and poverty seem to be strange bedfellows. The question can indeed be asked whether the concepts of religion and poverty belong together in the same sentence. Poverty refers to the absence of sufficient sustenance to maintain a complete life. This completeness refers to the provision on different levels of human existence, whether it be physical food and shelter or psychological security or political freedom. Although the terms 'sufficient' and 'complete' are totally arbitrary, a minimum standard as to what is considered 'sufficient' and 'complete' is to be deduced from other definitions of poverty. The definitions by the United Nations (UN) and the World Bank may be particularly helpful in this regard. The bottom line is that poverty functions on a horizontal level focusing on human earthly existence. Religion on the other hand transcends in a vertical trajectory earthly and material human concerns towards that which is deemed to be spiritual. In this regard, religion and poverty seem to be concerned with different human spheres of existence: poverty with earthly concerns and religion with spiritual concerns.

Humans are created matter. But humans are of a dual nature: part matter and part spirit, thus indicating a connection to a spiritual dimension. Man is not only matter, but spirit as well. Plato pointed to this dual human existence: the body is matter and belongs to this earth, but the soul is spirit and belongs to a different dimension (Russell 2010:134). Socrates explored this idea further and suggested (cf. Phaedo) that the body is of lesser value. The soul is of superior value and worth engaging with (Russell 2010:134). This anti-material position created an aversion for anything encountered through the senses. It led to the notion that all material matter is there only to sustain the human body, the consequence being that the perception is created that there is no intrinsic value in matter.

The soul engages with the spiritual, transcendental dimension. The expression of this transcendental concern may take on material form. The transcendental is thus expressed in terms of what is familiar in terms of sensory experience. Poverty can be relegated to the field of material existence and religion to the spiritual dimension. As to these two seemingly divergent fields, debate between religion and poverty seems unlikely. This article endeavours to identify possible areas where religion can contribute to the debate on poverty.

The way in which this is carried out, is by identifying basic principles as expressed in different religions on how poverty can be viewed and treated. This is not a theological exercise to judge the correctness or validity of any religious position, but rather a neutral religious study where religion is viewed as a human phenomenon. The different religions' perspectives on poverty are presented in a comparative way. This approach can be deemed by some to be a phenomenological study. There are however enough critical remarks on the different religious positions to disqualify this as a mere phenomenological descriptive study.

The perspective provided by sociology furthermore plays an important role in this study. Poverty is viewed as a human condition, embedded in society (Geremek 1994:1). This implies 
that poverty has a context that must be taken into account. A generic strategy for alleviating poverty is therefore impossible. One of the distinct colours in the kaleidoscope of factors determining society is religion. Religion is a social activity influencing the understanding of and response to poverty. Poverty is embedded in a social context and can only be understood when the context is understood. It is however important to take note of the relationship between the position of the observer and the observed when studying society (Chryssides \& Geaves 2007:53). When investigating society, we are therefore investigating ourselves.

\section{What is poverty and what is religion?}

Poverty is a creature with many heads and several tails, as is religion. The different heads would refer to the different forms poverty and religion can assume in society. There are many expressions of poverty as well as of religion. The tails dragging behind would refer to the consequences, influences and the effects of religion or poverty on society. Some effects of religion on poverty might be positive whilst some might be negative. In the case of poverty it might be difficult to identify any positive effects on human existence.

As to a definition of poverty, there seem to exist a wide range of possible definitions. Instead of listing all possible definitions, a conscious decision for a selected few definitions is made here.

Geremek provides a substantive definition: from a social perspective Geremek (1994:3) defines poverty as 'the point at which the survival of the individual and of the family became threatened'. This broad definition however does not differentiate between possible threats and is therefore unsatisfactory. It is assumed that Geremek refers to the threat of physical survival as well as the threat of making progress in life. It is obvious that a distinction should be made between relative and extreme poverty (Geremek 1994:3). Du Toit (1996:18), in an attempt to define poverty, states that poverty operates on a scale ranging from 'absolute poverty' to 'relative poverty'. Again it remains the discretion of the individual to determine what is 'absolute' and what is 'relative poverty.' Olupona (2009:xi) refers to Illiffe's differentiation of poverty into two groups: '[T]hose who struggle continuously to preserve themselves and their dependants from physical want' and the 'poorest of the poor, whose poverty has reached epidemic proportions'. According to Illife (Olupona 2009:xi), most people living in Africa from time to time drift in and out of the first category of poverty. Even the definition by Geremek is not a complete substantive definition as it does not define the true essence of poverty completely.

Hershock (n.d.:40) suggests a functional definition of poverty: 'Poverty is an erosion of the attentive and situational resources needed, in any given situation, to orient it as a whole toward the resolution of suffering.' For Hershock the opposite of poverty would be an existence where one can freely relate. It remains arbitrary who then determines what the 'resolution of suffering' is. Traditionally the end to poverty was seen as introducing development programmes (Hershock n.d.:33). This modernistic understanding of development as progression has in many cases proven ineffective in alleviating poverty.

An arbitrary definition of poverty as provided by David Gordon (2005:4), is accepted by the UN: '[F]undamentally, poverty is the inability of getting choices and opportunities, a violation of human dignity. It means the lack of basic capacity to participate effectively in society.' This extensive definition continues to list all possible forms of deprivation (i.e. food, education, medical treatment, self-provision, non-access to credit, powerlessness, violence, poor sanitation, etc.).

The World Bank (n.d.:1) defines poverty as follows: ' $[P]$ overty is deprivation in well-being, and comprises many dimensions.' Again the list of forms of deprivation that follows on the definition is quite extensive but not different from the list provided by the UN's analysis. It is therefore clear that poverty has many ways (heads) of presenting itself.

The degree of poverty is culturally determined. The ways in which one culture consumes and generates income, differ from another. What is considered to be deprivation in one culture can be viewed as excessive luxurious in a different culture. To have only one fish to eat per day might be considered extremely poor in certain communities, but in some instances one fish per day can be seen as true abundance. This illustrates the contextuality of poverty as mentioned before.

Geremek emphasises the role of economic indicators when defining poverty. Economy can however no longer be regarded as the sole measure for poverty (Geremek 1994:3). Poverty entails social, cultural, economic, political, psychological, physiological and ecological factors, encapsulating the complete human existence referred to in the introduction (Geremek 1994:4). These factors can cause a segment of society to be excluded from an economic system. Poverty can also be defined as 'a deterioration of one's material condition' or as 'a reduction in one's share of

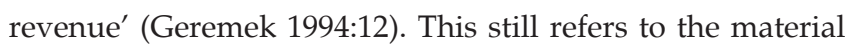
perspective on poverty.

Poverty consists of many facets. Self-induced poverty is different from poverty as a result of being the victim of a discriminatory system. Value judgements can determine whether poverty was because of laziness or bad planning on the side of the poor ${ }^{1}$. To remain poor even though working hard is possible within an oppressive and unfair economic system. The poor must also be seen as a social stratum within society. Class differences in society cause the less affluent to be regarded as a separate (inferior) social category.

When referring to the concept of religion as understood in this article, the definition by Sundermeier (1999:17) is applied. Religion is the collective human response to the awareness of the transcendental. Religion is expressed in terms of rituals and

1.Compare the Jewish distinction of self-induced poverty (Zohar 2010:206) as to a life of poverty as a result of devotion in studying the Torah (Zohar 2010:211). 
ethics. These expressions are varied, causing a multitude of religious reactions (faces of religion). This definition emphasises the social aspect as well as the ethical function of religion. Both societal and ethical aspects of religion play an important role. As this article is not presented from a theological perspective, the religious studies perspective should clearly be noted. The main question would be to determine whether religion and poverty can be related, or formulated differently: does religion and poverty belong in the same discourse? A Platonic division of body and soul seems to keep the spiritual activities naturally separate from earthly (material) concerns. The fact of the matter is that many religions connect human material and spiritual existence. Many religions have an opinion on how the poor should be treated or viewed. This creates the opportunity to compare different religious positions on poverty as well as identify the role religion can play in social matters.

\section{Causes of poverty}

Geremek (1994:11) identifies capitalism as the origin of poverty. It is surely irresponsible to reduce the origin of poverty to one single aspect. Peculiarly enough poverty, according to Geremek (1994:11), contributed to the development of capitalism and simultaneously poverty resulted from capitalism. Along with capitalism came the processes of industrialisation and commercialism, fuelling an unstoppable economic engine. For many centuries capitalism was considered by some to be the solution to poverty (Geremek 1994:11). Currently the introduction of technology is considered by some to be the solution to poverty. Technology can for instance lead to developing more advanced agricultural machinery alleviating poverty through better farming techniques.

Studies quoted by Geremek (1994:5) indicate that the causes of poverty must be divided between internal and external causes. Certain human behaviour, like laziness, may contribute to the condition of poverty. In some cases the poor however become victims of an oppressive or discriminating system.

\section{Effects of poverty}

The gravest effect of poverty, as identified by Geremek (1994:4), is the degradation of human dignity associated with it. Society has become accustomed to look upon poverty with disdain (Geremek 1994:6). Compare in this regard the definition of poverty by the UN (Gordon 2005) where poverty is viewed as a 'violation of human dignity'. Economic inequality contributed to social inequality, resulting in viewing poor people as less than human (Geremek 1994:5). Compare Mveng's indication of the gravest effect of poverty as the denial of one's very humanity (Olupona 2009:xi). This effect of poverty on society is one of the tails dragging in the sand behind the creature called poverty.

Poverty can be stigmatised. In some religious traditions poverty is seen as 'deservedly' so (Geremek 1994:6). Compare in this regard the view that poverty is regarded as punishment (by some Christians) or explained as the result of bad karma (by some Hindus). The attitude towards the poor might also be religiously determined. Charity is not necessarily directed at the poor, but to the benefit of the one showing charity: creating good karma or accumulating good deeds which will be rewarded.

Over centuries society responded differently to poverty (Galston \& Hoffenberg 2010:1). Poverty was prevalent already amongst pre-industrialised societies ${ }^{2}$ : therefore the role of capitalism and industrialisation as the origin of poverty could be questioned. The attitude towards poverty ranged over centuries from 'glorification to acceptance to censure' (Geremek 1994:7) to today where the poor is looked upon by some in disdain.

Du Toit's analysis of poverty states that poverty consists of material, cultural as well as spiritual poverty. He suggests that poverty should be understood not only in a quantitative but also in a qualitative way (Du Toit 1996:17). This places the discussion of poverty in the discourse of values. Discussions from a religious point of view can contribute to the debate on poverty as religion is expressed in terms of ethics (cf. Sundermeier 1999:17). This implies that religion and poverty are connected when discussed from a qualitative perspective.

Loy suggests that when attempting to define poverty, the search must be to identify what is considered to be truly poor. According to him that which makes people truly poor is the absence of moral quality (Loy 2008:3). Loy is however unclear as to who determines the measure of this moral depravity. It must however be stated clearly that religious affiliation does not determine moral quality. People with no religious affiliation can also possess moral quality (cf. Krüger, Lubbe \& Steyn 2009:294). Poverty cannot be measured only in terms of material conditions. Loy (2008:4) suggests that the true problem of society is not the unequal distribution of technological and economic value, but rather the psychological and spiritual need of humans to understand their own minds. This links with Du Toit's notion to measure poverty qualitatively instead of quantitatively. Poverty manifests itself materialistically, culturally or spiritually (Du Toit 1996:17).

It might in some circles be considered insensitive to reduce poverty only to spiritual forms. To reduce poverty to cultural, moral or spiritual aspects does nothing to alleviate material and existential poverty. Olupona (2009:x-xi) argues that religion needs to play a role in alleviating poverty as it presents itself in current society in all its forms. Poverty is often associated with other social evils such as violence, bribery, corruption (Olupona 2009:xi), exploitation, prostitution and discrimination against women and children 2.The majority of the population in the Roman Empire during the first centuries was considered to be poor. 
(Olupona 2009:xviii). These secondary effects of poverty can be viewed as the tails dragging behind in the sand.

\section{Solutions}

The traditional (modernistic) considerations of solutions to poverty consisted of the rooting out of the causes of poverty. Bringing about development through introducing technology and proper education would gradually cause poverty to disappear. By taking the correct measures poverty will be eradicated. The results of these measures were however not considered.

Hershock (n.d.:34) is convinced that when development does not alleviate poverty, it will definitely create an environment conducive to poverty and lead to the institutionalisation of poverty. Poverty will persist as the inability to meet one's own needs (Hershock n.d:36).

\section{What is the role of religion regarding poverty?}

The unique contribution religion can make to the debate on poverty, is threefold. Firstly, religion can redirect human attention to that which ought to be an ultimate concern. Secondly, religion provides the ethical fibre to society in order to respond appropriately to poverty. Lastly, it is the responsibility of religion to alleviate poverty.

When discussing religion, the danger of universalising it exists. Religions differ from context to context. Buddhism in Thailand for instance differs from Buddhism in South Africa. This is true of all major world religions ${ }^{3}$. Religions can be expressed differently in different contexts. Responses to poverty can take on different forms in different contexts although the religious affiliation may remain the same. This article is well aware of the danger of universalising.

\section{Redirected concern}

Hershock (n.d.:36) is convinced that alleviating poverty is about restoring relationships. In order to be in a harmonised relationship with the self, the other and the universe, one needs to direct attention in the correct direction. For Hershock (n.d.:36) poverty is about misdirected attention. Religion must redirect the focus and remind what humans' ultimate concern is. For Hershock (n.d.:37) Buddhism teaches the renouncing of material wealth and the seeking of 'noble wealth', which consists of building up faith, moral character and wisdom. These endeavours will prevent suffering, of which poverty is a form.

This advice to redirect attention to 'higher values', is echoed in Christianity. Compare Paul's encouragement to seek things which are above and more valuable than earthly things (Col 3:2). Also compare Jesus' recommendation that 3.For the sake of the argument traditional African religions are included. his followers create heavenly treasures instead of focusing on earthly valuables (Mt 6:19).

Hershock's (n.d.:35) emphasis on creating interdependence and establishing relationships and so ending poverty, is echoed in Christianity's emphasis on interdependence. Compare Matthew 5:3 emphasising the blessing the poor will receive because they realise their dependence on God as they have no one else to take care of them. The Christian command to love thy neighbour as thy love thyself ( $\operatorname{Lv} 19: 18$; Mt 22:39) encourages interdependence by way of love.

Max Weber is of the opinion that a love for the material world takes away the attention paid to the spiritual world (Weber 2003:42). Attention paid to the material world is, according to Weber (2003:40), true of the Protestant form, especially Calvinism, of Christianity. Calvinism is the seedbed for capitalism (Weber 2003:43). There however exist different Christian reactions: for example Franciscans and Lutherans subscribe to a more prudent lifestyle as opposed to Calvinism. Weber is however correct in that some Christian positions can in this way contribute to secularisation. Religion should have the opposite effect: religion should redirect concern to the spiritual existence (cf. Loy 2008:5).

It is however not easy to declare a new direction of attention. A worldview determines the view on poverty. For example, traditional African religions (especially Yoruba religion) have a this-worldly worldview (Olupuna 2009:xii) focusing on the lifestyle whilst alive. There is no consideration of the afterlife. Blessings of wealth and health in this worldly existence are considered as gifts from the gods. Poverty is seen as duly punishment for transgressions against the gods. The focus is mainly on this-worldly existence. Religion should open up an awareness of an existence after this life.

According to Weber's analysis, Protestants (read Calvinists) seem to be more prone to economic rationalism (Weber 2003:40). Weber suggests that Protestants (read Calvinists) especially seem to promote rationalism as a means to find prosperity (Krüger et al. 2009:277). Wealth and worldly prosperity have also (compare the Yoruba belief above) been interpreted by Protestant groups to indicate the blessing and grace the transcendental has bestowed upon them (Weber 1966:108,148). This love for the material and worldly possessions that has been identified with the Protestants (read Calvinists) will eventually distract attention from religion (Weber 2003:42) and therefore lead to secularisation (Weber 2003:40).

Weber's theory indicates further that different social classes have different functions for religion. For the economic privileged classes, religion does not need to produce salvation. Religion for the economic privileged has the function of legitimising their life pattern and social status in society (Weber 1966:107). For Weber it is also clear that there is a connection between social well-being and divine approval. Good fortune experienced by the individual is therefore 
a sign of divine approval. The opposite, namely poverty, being divine disapproval of existence as expressed in human misfortune (Weber 1966:108). Good fortune of the privileged is then legitimised religiously. For the underprivileged or disprivileged classes of society their need for salvation finds expression in various forms of religion (Weber 1966:108). In Hindu belief the deplorable condition of those belonging to the Pariah group, is seen as their deserved reward for accumulating excessive bad karma (Sharma 2010:171). Poverty in this regard is then religiously institutionalised.

It should be pointed out that human existence is not only reduced to a this-worldly, material existence. Poverty belongs to this world. Existence in this world is of course important, but there is so much more. Human existence should also focus on the spiritual existence. Religion has the task to remind humanity of completeness only attainable through engaging the spiritual as well as the material existence.

\section{Ethical function}

Religion has an ethical role to play when it comes to poverty. De Beer refers to the position taken by Emmanuel Levinas to emphasise that ethics precede knowledge. An ethical treatment of a matter precedes knowledge thereof (De Beer 1996:44). Levinas (1981:10) in discussing essential human nature, reminds us that as living beings humans have a responsibility towards one another. This responsibility is expressed by way of the good (Levinas 1981:11). In a treatise on human nature Buijs (2005:171) indicates that the acts of goodness in humans are questionable. Buijs's scepticism is based on Ricoeur's hermeneutic of suspicion. Acts of goodness towards others is not necessarily performed with a selfish reason, he concludes (Buijs 2005:178). Humans react in goodness towards others based on gratitude for what they have received (Buijs 2005:179). Religion reminds humans of human nature, to seek selflessly the benefit of others. Altruism is a human trait which emphasises the human responsibility for others (Buijs 2005:170).

The responsibility towards the poor is not only a biblical imperative but also a humanitarian imperative (Mabuza 1996:1). Mabuza suggests that taking care of the poor is not only a religious obligation but a humanitarian affair as well. This outlook combines the religious with the anthropological view on poverty. The major world religions emphasise the responsibility to give to those in need. Judaism and Islam have institutionalised this obligation to give to the poor by way of zakat in Islam (Hashmi 2010:180) and tzedakah in Judaism (Zohar 2010:212). The gift to the poor is an obligation.

The possibility however exists that religion can maintain and contribute to poverty. This has been alluded to by referring to Weber's description of Calvinism's support for capitalism as religious value. This highlights the dark side of some religious values supporting poverty amongst some classes in society. As to the positive effect of religion on poverty, the question is how can the ethical task of religion address the issue of poverty?

\section{Religion must teach society proper values and principles to be applied in economic systems}

The solution to poverty suggested by Du Toit (1996:25) is to change the needs of people. Human needs are biologically constructed and socially determined. The basic biological needs for food and shelter cannot be changed. The approach to fulfilling these needs can however be changed. The solution is to change social values in order to change the attitude towards basic needs (Du Toit 1996:26).

Wealth and power are in many societies considered synonymous. Those with wealth have the power to control the lives of the poor. The current capitalistic value system maintains differences between the poor and the rich. It would be more appropriate if an economic system were driven by fair values, enabling survival of all (Du Toit 1996:30).

Hershock (n.d.:52) indicates how certain values in current economic policies maintain poverty. Through effective advertisement the need is created to consume. The excessive availability of credit further makes it easier to buy and fall into debt. More employment opportunities (Hershock n.d.:52), especially for women, increase expendable income and can stimulate greed. Social status is constructed in terms of what one possesses. The more I have, the higher my social standing. These values stimulate consumption and create the illusion that poverty can only be alleviated by increased consumption (Hershock n.d.:54). The more I have, the richer I appear: while, in fact, in trying to possess more I become poorer. The consumption driven economy urges cheap production in order to participate in a competitive market. The result is exploitation of labour and resources.

The illusion is created that a proper life is a life of consuming goods. Loy (2008:4) suggests that a 'happy life' should not be measured in terms of income but in terms of well-being. With 'well-being' the all-encompassing levels of deprivation as identified by the UN and World Bank, need to be addressed. Well-being does not consider consumption. These values applied in current economic systems need to be revised. Religion can suggest values that can redirect attention away from selfish greed and the need to own and consume. Values of contentment and finding well-being without consumption should be part of an economic system.

Olupona suggests (2009:xvi) that members of religious affiliations encourage governments to be intolerant towards corruption, to create skills-development programmes among local people, and to persuade Western governments not to give tax relieves to companies who contribute to environmental disasters. These are some examples of sound values to be implemented in an economic system which can alleviate poverty.

Non-governmental organisations (NGOs) with close ties to religious factions can contribute to the discussions on the causes of poverty. The NGOs can create awareness of the contributing factors to poverty by keeping the topics on the 
agenda in discussions with government. Olupona (2009:xvi) attests to the successes reached by the Catholic social justice lobbying group, called Network, who continuously asks government and corporations ethical questions on economic policies. By asking how do government economic policies affect the poor or how do policies alleviate and prevent poverty, government and industry leaders will become aware of the problem and the urgency to address it through creating policies conducive to alleviating and even eradicating poverty.

Societies can reconstruct value systems. Only societies can reinforce what is of true importance in human life. Hershock (n.d.:37) indicates that poverty is not determined by the absence of material elements, but rather the response to the absence. Society needs a reorientation to what is truly necessary for a complete existence (compare what has already been mentioned in the Redirection of Attention above). These religiously determined values will temper and influence growth and consumption driven economic developments.

\section{Religion must teach society the moral obligation of generosity}

Marcell Mauss (1990:18) when writing on human nature, states that generosity is an obligation. Whether generosity is a human trait being exercised under all conditions is questionable. Self-preservation weighs heavier than selfsacrifice. Generosity does not come naturally, but can be encouraged. It was the traditional way and ought to be the way in which humans meet each other in society (Mauss 1990:18).

What is needed is an adjustment in human attitude towards material elements. The minimum human needs, according to a Buddhist understanding, are food sufficient to prevent hunger and maintain health, clothing sufficient to appear socially decent and to protect the body from the natural elements, housing which provides shelter and security and medicine to prevent disease (Premasiri 1999:3). More than this is considered excessive. Compare the Jewish prayer reflecting this attitude:

Give me neither poverty nor riches, but give me only my daily bread. Otherwise I may have too much and disown you and say, 'Who is the Lord?' Or I may become poor and steal, and so dishonour the name of my God. (Pr 30:8)

The greatest wealth according to the Buddhist teaching (Premasiri 1999:4) lies in being content. Contentment tempers the need to own and consume. Contentment creates the possibility to share and redistribute resources. Contentment is however only possible when basic human needs are met. If I have what is necessary to survive I can share with others.

Loy (2008:7) suggests that the function of religion when it comes to poverty is to provide a moral framework for society. Members of society should be made aware of their moral responsibility towards members of society (Loy 2008:7). Generosity should be the guiding principle when responding to poverty (Loy 2008:9).
Maimonides, the medieval Jewish philosopher, deals in his commentary on the Talmud (Mishna Torah) in chapter 10:7-14 entitled Hilkot matanot aniyim [Laws about giving to the poor] with giving to the poor. According to Maimonides it is best to give a loan to a poor person in order to enable that person to make a living instead of begging. Such a gift is best given anonymously, willingly and with sympathy. A gift to the poor (tzedakah) is best given before it is asked for. This attitude illustrates generosity towards the poor.

\section{Religion must assist in restoring and maintaining human dignity}

As has been indicated earlier, poverty has the effect of creating class differences in society, causing the affluent to look upon the poor with disdain. Nobody should look down on the poor with disdain (Geremek 1994:5) as if the poor is inferior or lesser human beings. The problem is that economically poor can be equated with spiritually poor.

Olupona (2009:xix) states that in order for peace to prevail, the restoration of the spiritual sanctity of life is necessary. Religion has the obligation to remind society of the equality of human existence. Human beings cannot be classed and categorised according to the level of affluence. Society should secure the sanctity of life for all members of society. Religion provides the moral fibres enabling society to perform this task.

\section{Poverty alleviation}

The role of religion when it comes to poverty can never be reduced to merely sympathy and well-wishing, nor empty words of comfort by emphasising a better future still to come.

People with different religious affiliations need to play an active role in attempting to alleviate and if possible eradicate poverty. Religion should create awareness of the problem of poverty. Human beings still exist in this-worldly life. Religion may redirect attention to a higher, spiritual existence in future, devoid of material needs. It still does not change the existential effects of poverty.

Olupona (2009:xv) emphasises the contribution faithbased initiatives can make in poverty alleviation. In Islam the principle of zakat [the obligatory gift to the poor] has exactly this function to maintain the integrity of the umma [community] (Hashmi 2010:183) by distributing wealth so that none in the community will go wanting (Hashmi 2010:186).

Religiosity is a growing phenomenon. Research carried out by Norris and Inglehart (2011) indicates how religion is growing especially amongst poor and oppressed communities. A feeling of insecurity, a lack of food and survival for example create the seedbed for religion. A feeling of dependence amongst the oppressed and the poor, increases religious activities. Corrupt religious leaders can in such oppressed communities however extort money from the poor in exchange for promises of wealth. Olupona (2099:xvi) 
confirms that in Africa the most impoverished people tend to be deeply spiritual.

Olupona (2009:xvii) suggests that faith-based communities work together with institutions to alleviate poverty. He suggests cooperation with the International Monetary Fund and World Bank in order to support the poor. Faith-based communities are considered to be credible partners and can assist the institutions in redistributing resources amongst local communities. The faith-based communities should however, according to Olupona (2009:xviii), maintain their prophetic calling by continuously commenting on global financial policies and must express a discomfort with unjust policies to the trade and industry community.

These faith-based communities provide a primary support network for families and dislocated individuals. Not only is the support in terms of material provision but faith-based communities also provide a sense of belonging and identity (Olupona 2009:xvi). This restores the human dignity to those in material need. The willingness to assist, Olupona states (2009:xvi), is based on ancient religious teachings, values and morals encouraging assistance to those in need.

The danger with diakonia [service to those in need] as a way of alleviating poverty is however twofold: humanitarianism and proselytising. Serving those in need only to relieve their material need ends up as humanitarianism based on philanthropy. The religious character is lost as humanitarian assistance is mainly focused on relieving material need. In addition to this religions can view the assistance to the poor as a means to convince them to convert to a particular religion. Assistance to the poor then becomes a missionary tool. The true agenda is not maintaining the sanctity of life, but expanding the borders of a religion. These pitfalls should be kept in mind when religions attempt to alleviate poverty.

Another danger is that of reductionism. Reducing the solution to poverty to the spiritual or ethical levels, is dangerous. Instead, when expressing concern about poverty, it should be holistic, keeping all needs of humans in mind. Olupona (2009:xvi) suggests a balance between religious endeavour to save souls as well as to address misery and poverty. The thisworldly and other-worldly concerns need to be in harmony and addressed equally.

\section{Conclusion}

Poverty is nothing new and seemingly will never end. How society has responded to poverty over centuries has changed. There is however not only one way in which societies respond to poverty. The response to poverty is contextual. Each society responds to poverty in a different manner, as determined by economic, political, cultural, psychological, philosophical and traditional factors as well as religious convictions.

Religion can play a role in addressing poverty. Religion not only becomes the moral consciousness reminding society of being generous to the poor but also seeing the poor as fellow human beings. Religion can also create a new matrix of thought, influencing the values of society. A society with a high regard for materialism and consumption, needs to take note of an existence stretching further than earthly life that includes a connection to a spiritual realm. The earthly material existence is a reduction of human existence. Societal thought needs to be redirected.

Religion not only functions in an ethical and ideological capacity when responding to poverty. Religion can motivate people to engage actively in participating in activities alleviating poverty. The balance is restored when poverty is not only measured in terms of ethical and spiritual measures, but also in attempts to provide the material needs of the poor.

True wealth does not lie in material possessions. Freedom to exist carefree is an asset. Religion can contribute to experiencing the fullness of life in all its forms.

\section{Acknowledgements Competing interests}

The author declares that he has no financial or personal relationship(s) that may have inappropriately influenced him in writing this article.

\section{References}

Buijs, G., 2005, 'Homo donans. Waarom wij ons (soms) voor anderen inzetten', in G. Buijs (red.), Homo Respondens: Verkenningen rond het mens-zjin, pp. 169-179, Buijten \& Schipperheijn Motief, Amsterdam.

Chryssides, G.D. \& Geaves, R., 2007, The study of religion: An introduction to key ideas and methods, Continuum, London.

De Beer, C.S., 1996, 'Thinking and poverty', in C.W. du Toit (ed.), Empowering the poor: A compilation of papers presented at the twentieth symposium of the Research Institute for Theology and Religion, University of South Africa, Pretoria, South Africa, 04-05 September, 1996, pp. 37-47.

Du Toit, C.W., 1996, 'Empowering the poor: Changing our minds on affluence and poverty', in C.W du Toit (ed.), Empowering the poor: A compilation of papers presented at the twentieth symposium of the Research Institute for Theology and Religion, University of South Africa, Pretoria, South Africa, 04-05 September, 1996, pp. 10-31.

Galston, W.A. \& Hoffenberg, P.H., 2010, Poverty and morality: Religious and secular perspectives, Cambridge University Press, Cambridge. http://dx.doi.org/10.1017/ CBO9780511779084

Geremek, B., 1994, Poverty: A history, transl. A. Kolakowska, Blackwell Publishers, Oxford.

Gordon, D., 2005, Indicators of poverty \& hunger, viewed 07 April 2014, from www. un.org/esa/socdev/unyin/documents/ydiDavidGordon_poverty.pdf

Hashmi, S.H., 2010, 'The problem of poverty in Islamic ethics', in W.A. Galston \& P.H. Hoffenberg (eds.), Poverty and morality: Religious and secular perspectives, $\mathrm{pp}$. 180-203, Cambridge University Press, Cambridge. http://dx.doi.org/10.1017/ CBO9780511779084.010

Hershock, P.D., n.d., Poverty alleviation: A Buddhist perspective, viewed 06 March 2013, from http://himalaya.socanth.cam.ac.uk/collections/journals/jbs/pdf/ JBS_11_03.pdf

Krüger, J.S., Lubbe, H.J.A. \& Steyn, H.C., 2009, Human search for meaning, Van Schaik Publishers, Pretoria.

Levinas, E., 1981, Otherwise than being or beyond essence, transl. A. Lingis, Kluwer Academic Publishers, Dordrecht.

Loy, D.R. 2008, 'Advancing legal empowerment of the poor: The role and perspective of Buddhism', in Religions for piece, viewed 06 March 2013, from www. religionsforpeace.org/file/.../legal-empowerment/buddhism-and-legal.do

Mabuza, W., 1996, 'The struggle continues', in C.W. du Toit (ed.), Empowering the poor: A compilation of papers presented at the twentieth symposium of the Research Institute for Theology and Religion, University of South Africa, Pretoria, South Africa, 04-05 September, 1996, pp. 1-9. 
Mauss, M., 1990, The gift: The form and reason for exchange in archaic societies, transl. W.D. Walls, W.W. Norton, New York.

Norris, P. \& Inglehart, R., 2011, Sacred and secular: Religion and politics worldwide, 2nd edn., Cambridge University Press, Cambridge. http://dx.doi.org/10.1017/ CB09780511894862

Olupona, J., 2009, 'Understanding poverty and its alleviation in Africa and the African diaspora: An interdisciplinary approach', in P.J. Paris (ed.), Religion and Poverty: Pan-African Perspectives, pp. ix-xxiii, Duke University Press, Durham.

Premasiri, P.D., 1999, Religious values and the measurement of poverty: A Buddhis perspective, viewed on 06 March 2013, from http://siteresources.worldbank.org/ INTPOVERTY/Resources/WDR/johannesburg/buddhist.pdf

Russell, B., 2010, History of Western Philosophy, Routledge Classics, London.
Sharma, A., 2010, 'Hinduism and poverty', in W.A. Galston \& P.H. Hoffenberg (eds.), Poverty and morality: Religious and secular perspectives, pp. 160-179, Cambridge Poverty and morality: Religious and secular perspectives, pp. 160-179, Cambridge
University Press, Cambridge. http://dx.doi.org/10.1017/CBO9780511779084.009

Sundermeier, T., 1999, Was ist Religion? Religionswissenschaft in theologischem Kontext, Gütersloher Verlagshaus, Gütersloh.

Weber, M., 1966, The sociology of religion, transl. E. Fischoff, Methuen and Co, London. Weber, M., 2003, The Protestant ethic and the spirit of capitalism, transl. T. Parsons, Charles Scribner's Sons, New York.

World Bank, n.d., Poverty research, viewed 07 April 2014, from www.worldbank.org/ en/topic/poverty/research.

Zohar, N., 2010, 'Jewish perspectives on poverty', in W.A. Galston \& P.H. Hoffenberg (eds.), Poverty and morality: Religious and secular perspectives, pp. 204-219, Cambridge University Press, Cambridge. 